\title{
KKN-M Pendampingan Belajar dari Rumah pada Masa Pandemi Covid- 19 untuk Anak SD di Desa Bamo Kecamatan Kota Komba Kabupaten Manggarai Timur
}

\author{
Maria Angelina Gua ${ }^{*}$, Elfrida Yosefina Marlon ${ }^{2}$, Adrianus Nasar ${ }^{3}$ \\ 1,2,3Universitas Flores, Ende, Indonesia \\ *Corresponding Author: mariaangelinagua@gmail.com
}

\begin{abstract}
Info Artikel
Diterima : 28/08/2021

Direvisi: 10/09/2021

Disetujui: $14 / 09 / 2021$

Abstract. Community service activities were carried out in Bamo Village, Kota Komba District, East Manggarai Regency. The purpose of this community service activity was to conduct tutoring assistance activities for elementary school students during the Covid-19 pandemic. Where tutoring activities were carried out by gathering elementary school students in one house. The implementation of independent KKN by Flores University students is carried out in three stages, namely introduction, implementation of activities and results of activities. The implementation of KKN is focused on a special theme, namely Innovation and Elementary Learning Technology. Learning innovation activities are carried out by utilizing technology tools in the form of a laptop. Where the laptop functions to play animated videos. And the results of the activities are documented in the form of videos and photos. The results of this learning innovation activity are where SDK Waepoang students are increasingly interested in participating in tutoring activities.
\end{abstract}

Keywords: Guidance, Covid-19, Animated video

\begin{abstract}
Abstrak. Kegaiatan pengabdian masyarakat dilaksanakan di Desa Bamo, Kecamatan Kota Komba, Kabupaten Manggarai Timur.Adapun tujuan dari kegaitan pengabdian masyarakat ini adalah untuk melakukan kegiatan pendampingan bimbingan belajar kepada siswa SD dalam masa pandemic Covid 19.Dimana kegitan bimbingan belajar dilakukan dengan cara mengumpulkan siswa SD dalam satu rumah.Pelaksanaan KKN mandiri oleh Mahasiswa Universitas Flores dilakukan dalam tiga tahapan yakni pendahuluan, pelaksanaan kegiatan dan hasil kegiatan. Pelaksanaan KKN difokuskan pada tema Khusus yakni Inovasi dan Teknologi Pembelajaran SD.Kegiatan inovasi pembelajaran dilakukan dengan memanfaatkan alat keknologi berupa leptop.Dimana leptop berfungsi untuk memutar video animasi. Dan hasil kegiatan didokumentasi dalam bentuk video dan foto. Adapun hasil dari kegiatan inovasi pembelajaran ini dimana siswa SDK Waepoang semakin tertarik untuk mengikuti kegiatan bimbingan belajar..
\end{abstract}

Kata Kunci: Bimbingan, Covid -19, Video animasi

How to Cite: Gua, M. A., Marlon, E.Y., \& Nasar, A. (2021). KKN-M Pendampingan Belajar dari Rumah pada Masa Pandemi Covid-19 untuk Anak SD di Desa Bamo Kecamatan Kota Komba Kabupaten Manggarai Timur. Prima Abdika : Jurnal Pengabdian Masyarakat, 1(3), 114-119. https://doi.org/10.37478/abdika.v1i3.1217

\section{Pendahuluan}

Desa Bamo merupakan salah satu desa yang berada di Kecamatan Kota Komba, Kabupaten Manggarai Timur, Provinsi Nusa Tenggara Timur. Sebagaimana daerah lainnya di Indonesia, Desa Bamo juga memiliki lembaga pendidikan yang menerapkan platform belajar dari rumah (BDR) akibat dari adanya penyebaran pandemic covid-19. Menurut UNESCO, banyak negara menutup sekolah untuk aktivitas belajar karena penyebaran covid-19 (Amalia \& Sa'adah, 2020). Pemerintah Republik Indonesia merespon kondisi perubahan platform belajar ini sebagai upaya pemenuhan hak peserta didik. Tanggapan pemerintah ini ditindaklanjuti oleh Kementerian Pendidikan dan Kebudayaan melalui Surat Edaran Nomor 4 tahun 2020 tentang Pelaksanaan Kebijakan Pendidikan dalam Masa Darurat Penyebaran Coronavirus Desease (Covid-19). Dalam surat edaran ini, kebijakan pendidikan dalam masa darurat penyebaran covid-19 dilaksanakan melalui proses Belajar dari Rumah (BDR) (Kemendikbud_A, 2020). 
Proses BDR dituang dalam Pedoman Pelaksanaan Kebijakan Belajar Dari Rumah (BDR) selama darurat COVID-19 yang dikeluarkan oleh Sekertaris denderal Kemendibud. Tujuan dari pedoman ini adalah untuk memastikan hak anak untuk tetap mendapatkan layanan pendidikan, melindungi warga satuan pendidikan, mencegah penyebaran dan penularan COVID-19 di satuan pendidikan dan memastikan pemenuhan dukungan psikososial bagi pendidik, peserta didik dan orang tua/wali (SekJend_Kemendikbud, 2020). Salah satu prinsip BDR ini adalah mengedepankan pola interaksi dan komunikasi yang positif antara guru dengan orang tua/wali (SekJend_Kemendikbud, 2020). Interaksi yang positif ini dilaksanakan secara konkret melalui pendampingan dan bimbingan belajar pada proses BDR selama Pandemi Covid-19. Pendampinan bimbingan belajar merupakan proses pemberian bantuan atau pertolongan baik bagi individu maupun kelompok oleh seorang atau lebih pembimbing yang memiliki keahlian di bidang tersebut dalam menentukan pilihan, penyesuaian serta pemecahan masalah belajar yang berkaitan dengan perubahan tingkah laku sebagai akibat dari pengalaman, latihan maupun rangsangan (Rosaria \& Novika, 2018).

Penyebaran pandemic covid-19 juga berdampak pada pelaksanaan tridharma perguruan tinggi seperti pada aspek pengabdian kepada masyarakat melalui kuliah kerja nyata $(\mathrm{KKN})$. Pada masa pandemic, pola pelaksanaan KKN mengalami perubahan platform yaitu dengan memanfaatkan perkembangan teknologi informasi. Melalui kegiatan KKN mahasiswa diharapkan dapat berkontribusi terhadap permasalahan masyarakat yang terdampak pandemi Covid-19. Salah satu cara yang bisa dilakukan adalah dengan memberikan pemikiran dan bekerja sama secara sistematis dalam rangka penanganan Covid-19 berdasarkan kualifikasi bidang studi masing-masing. Mahasiswa juga dapat memahami dan mencarikan solusi atas kesulitan/permasalahan yang dihadapi masyarakat khususnya dalam penanganan Covid-19, baik secara individual maupun kelompok (Ditjen Dikti Kemdikbud RI, 2020).

Universitas Flores, sebagai suatu perguruan tinggi, menyelenggarakan kegiatan pengabdian kepada masyarakat $(\mathrm{PkM})$ melalui KKN. Pada tahun akademik 2020/2021, KKN Universitas Flores dituangkan secara resmi melalui Surat Keputusan (SK) Rektor Nomor 17 Tahun 2021 (LPPM_UNIFLOR, 2021). Dalam SK ini disebutkan bahwa KKN merupakan salah satu bentuk pengamalan Tri Dharma perguruan Tinggi dan wahana belajar bagi mahasiswa untuk mengaplikasikan berbagai teori yang diperolehnya selama dalam perkuliahan sesuai dengan disiplin ilmunya masing-masing untuk meningkatkan kualitas kehidupan masyarakat. Mahasiswa peserta KKN Universitas Flores adalah mahasiswa yang telah memenuhi kriteria kelayakan yaitu telah mempelajari dan memahami konsep dan teori keilmuan bidang disiplinnya. Kategori ini menjadi dasar bagi mahasiswa bidang keguruan dan ilmu pendidikan untuk menjadi pendamping siswa selama BDR.

Selain itu, dalam SK Rektor tersebut disebutkan juga bahwa KKN merupakan media untuk membangun kemitraan lembaga perguruan tinggi dengan masyarakat. Sehubungan dengan pelaksanaan KKN mandiri yang dilakukan oleh mahasiswa di desa Bamo, Universitas Flores membangun kemitraan dengan Desa Bamo Manggarai Timur melalui Perjanjian Kerja Sama (PKS) (Rosaria \& Novika, 2018). Realisasi dari PKS ini adalah 
terlaksananya KKN mandiri yang dilakukan oleh mahasiswa program studi Pendidikan Biologi Fakultas Keguruan dan Ilmu Pendidikan Universitas Flores. Bentuk konkrit KKN mandiri oleh mahasiswa Universitas Flores di Desa Bamo Kabupaten Manggarai Timur adalah KKNM-pendampingan belajar dari rumah untuk anak sd pada masa pandemi covid-19. Tema utama KKN Universitas Flores adalah "MASYARAKAT TANGGUH DALAM MENGHADAPI COVID-19 BERSAMA KKN UNIFLOR 2021" dan sub tema "KKN-inovasi dan Teknologi Pembelajaran".

\section{Metode Pelaksanaan}

Pelakanaan KKN Mandiri oleh mahasiswa Universitas Flores di Desa Bamo Kabupaten Manggarai Timur dilaksanakan melalui tahapan yaitu pendahuluan, pelaksanaan kegiatan, dan hasil kegiatan. Tahapan pendahuluan mencakup gambaran analisis situasi Desa Bamo, menguraikan masalah yang ditemui, dan tawaran atau solusi untuk mengatasi permasalahan (P3KKN_UNIFLOR, 2021). Kegiatan pendahuluan ini menghasilkan suatu program kerja KKN selama satu bulan. Program kerja yang telah dibuat harus mendapat persetujuan dari kepada desa, dan setelah disetujui, maka tahap selanjutnya adalah sosialiasi program.

Pelaksanaan kegiatan oleh peserta KKN merujuk pada program kerja yang telah disusun sebelumnya. Pelaksanaan kegiatan KKN difokuskan pada tema khusus yaitu inovasi dan teknologi pembelajaran. Hasil pelaksanaan kegiatan diamati dan didokumentasikan dalam bentuk foto dan video rekaman. Selama pelaksanaan kegiatan ini mahasiswa didampingi oleh seorang dosen pendamping lapangan (DPL). Data pengamatan dan dokumentasi dianalisis secara deskriptif kualitatif.

\section{Hasil dan Pembahasan}

Berdasarkan tema kegiatan yang diambil maka kegiatan yang dilaksanakan berkaitan dengan bimbingan belajar untuk siswa SD. Kegiatan bimbingan belajar merupakan suatu proses pemberian bantuan kepada siswa dalam menyelesaikan masalah-masalah belajar yang dihadapi siswa, sehingga tujuan dari belajar akan tercapai. Berdasarkan pengertian dari bimbingan belajar maka, kegiatan bimbingan sangat penting untuk dijalankan. Namun, dalam melaksanakan kegiatan bimbingan belajar pasti ada saja tantangantantangan tersendiri yang dihadapi oleh guru. Tantangan-tantangan ini salah satunya adalah adanya pandemic covid-19. Adanya pandemic covid-19 menyebabkan kegiatan bimbingan belajar disekolah tidak berjalan secara efektif. Untuk mengatasi hal tersebut, maka kegiatan bimbingan belajar mengajar dilakukan secara during dengan cara mengumpulkan siswa dalam satu rumah kemudian memberikan bimbingan belajar. 


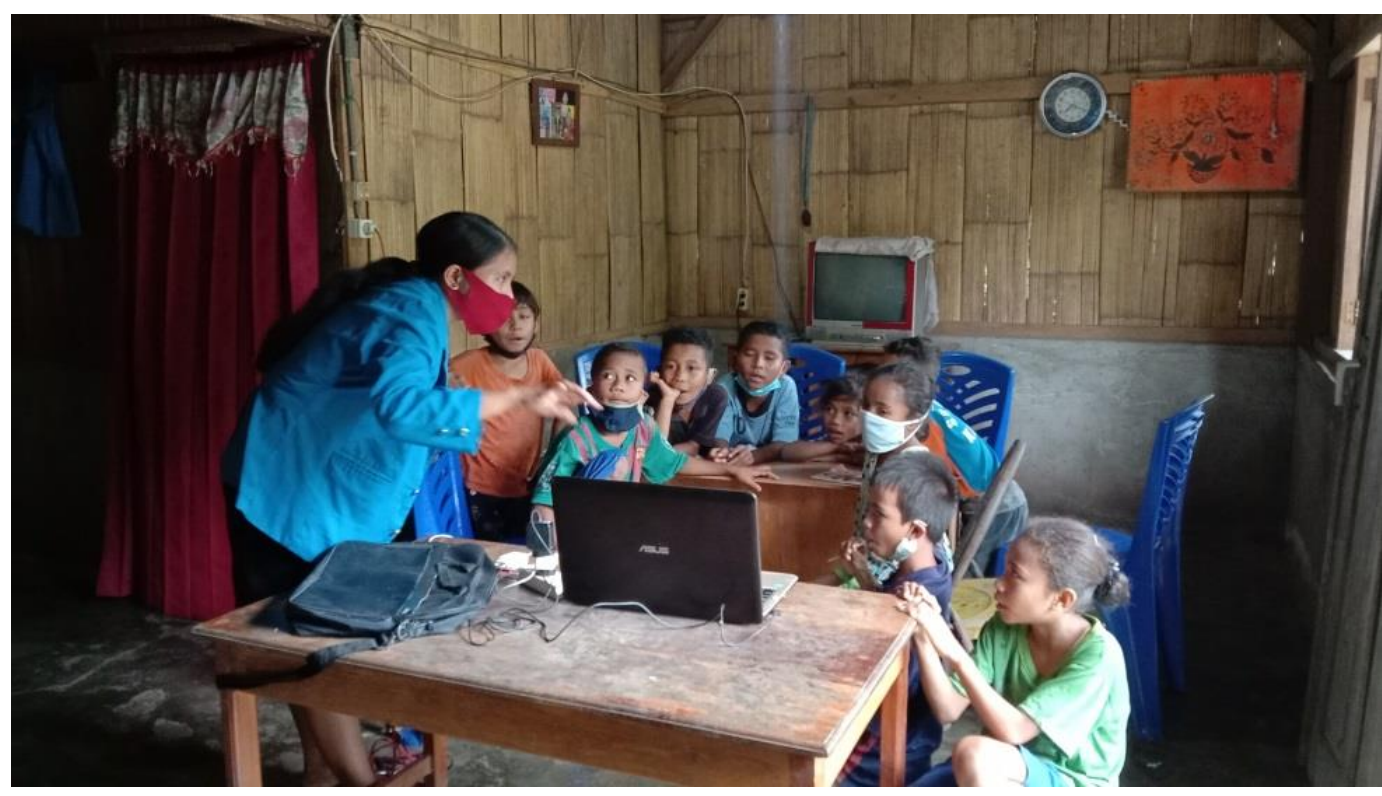

Gambar 1.Kegiatan bimbingan belajar secara luring

Agar kegiatan bimbingan belajar mengajar berjalan dengan baik dan tidak terkesan membosankan maka peserta KKN melakukan kegiatan Inovasi dan Teknologi dalam pembelajaran SD. Dimana kegiatan inovasi yang dilakukan oleh peserta KKN adalah dengan memanfaatkan alat teknologi. Teknologi pembelajaran merupakan metode yang diciptakan oleh manusia untuk mempermudah manusia lain memperoleh pengetahuan secara praktis yang bermanfaat baginya atau orang lain disekitarnya yang digunakan sebagai salah satu sumber belajar. Mengetahui akan pentingnya teknologi dalam pembelajaran maka, dalam melakukan kegiatan bimbingan belajar peserta KKN memanfaatkan teknologi untuk memudahkan dalam melakukan kegiatan bimbingan belajar kepada siswa.

Untuk itu, teknologi yang digunakan adalah berupa laptop. Dimana laptop merupakan salah satu alat teknologi yang memiliki manfaat yang besar bagi seseorang. Salah satu manfaat penggunaan laptop adalah untuk memutar Video animasi dan gambar. Alasan menggunakan media Video animasi karena Video animasi dapat menarik minat belajar siswa. Pada saat peserta KKN memberikan bimbingan belajar, siswa tidak merasa jenuh dalam mengikuti bimbingan. Alasan lain menggunakan media video animasi karena SD yang bersangkutan belum pernah menerapkan kegiatan bimbingan belajar kepada siswa dengan menggunakan media video animasi. Sehingga penggunaan media video animasi merupakan hal baru bagi siswa dan tentunya dapat lebih menarik minat belajar siswa. Video animasi yang diberikan kepada siswa tentunya berkaitan dengan materi yang akan diberikan kepada siswa. Manfaat penggunaan media video animasi juga di dukung oleh penelitian dari Rika Agustin, dkk. 2021 dalam jurnalnya yang berjudul Peran Media Interaktif Animasi Terhadap Minat Belajar Pada Mata Pelajaran Bahasa Indonesia Kelas IV SD Negeri 019 Tanjung Sawit Kecamatan Tapung Kabupaten Kampar. 


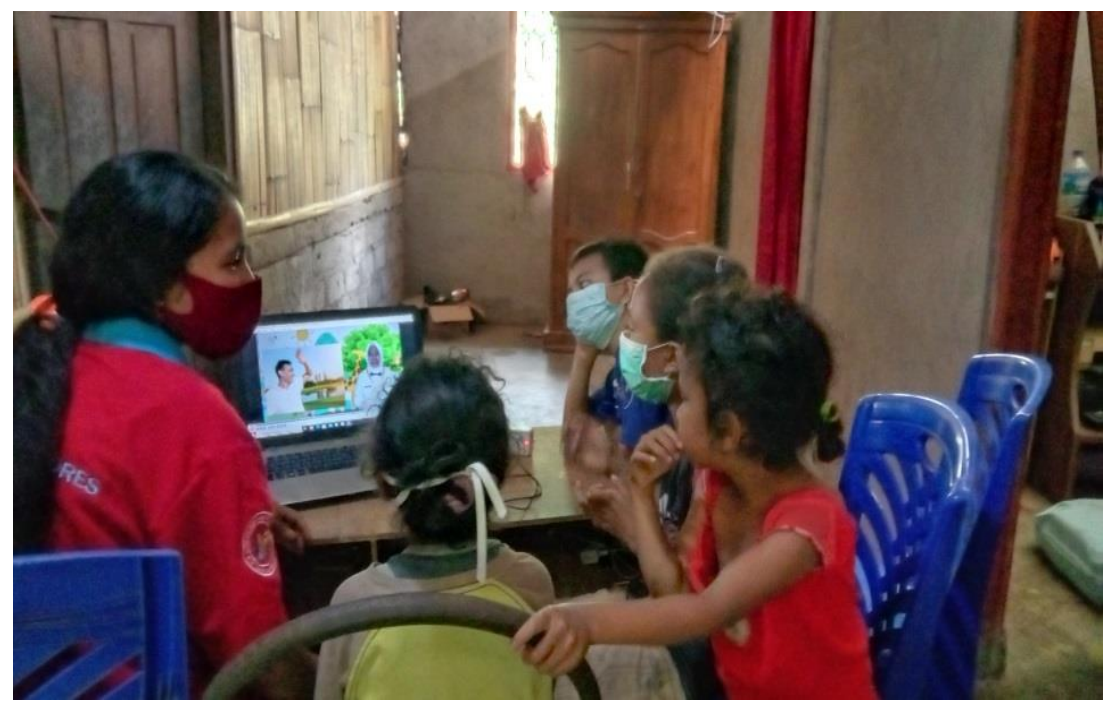

Gambar 2. Bimbingan belajar dengan menggunakan media video animasi

Kegiatan bimbingan belajar mengajar tetap dilaksanakan dalam masa pandemic covid-19 apabila Lembaga Pendidikan yang bersangkutan tetap mematuhi protokol kesehatan. Untuk itu, agar kegiatan bimbingan belajar mengajar tetap dilaksanakan maka peserta KKN selalu mengingatkan kepada siswa untuk selalu mematuhi protokol kesehatan seperti selalu menggunkan masker, memakai handseinitazer ataupun selalu menjaga jarak. Biasanya kegiatan ini dilakukan sebelum kegiatan bimbingan belajar mengajar dimulai.

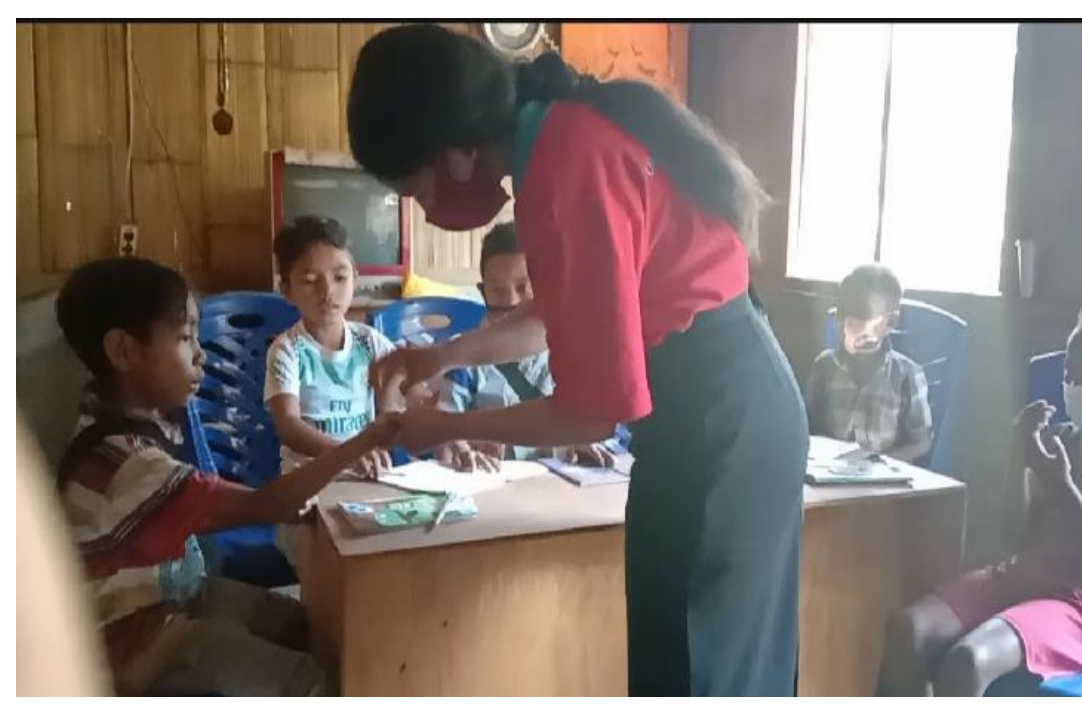

Gambar 3. Pembagian handseinitazer kepada siswa sebelum kegiatan bimbingan belajar mengajar dimulai

\section{Simpulan dan Tindak Lanjut}

Pelaksanaan KKN mandiri melalui pendamingan belajar siswa selama BDR di Desa Bamo Kabupaten Manggarai Timur dapat diambil kesimpulan, pertama, mahasiswa mampu menerapkan teori yang diperoleh di kampus 
dalam kehidupan nyata di masyarakat; kedua, terdapat kemitraan yang saling menguntungan antara Universitas Flores dan Desa Bamo Kabupaten Manggarai Timur; dan ketiga, ada respon posistif dari masyarakat dan siswa atas pendampingan yang dilakukan oleh Mahasiswa KKN Universitas Flores. Harapan selanjutnya agar kemitraan Universitas Flores dengan Pemerintah Desa Bao tetap berlanjut dan terwujud dalam kegiatan berbagai aspek.

\section{Daftar Pustaka}

Amalia, A., \& Sa'adah, N. (2020). Dampak Wabah Covid-19 Terhadap Kegiatan Belajar Mengajar Di Indonesia. Jurnal Psikologi, 13(2), 214-225. https://doi.org/10.35760/psi.2020.v13i2.3572

Ditjen Dikti Kemdikbud RI. (2020). Buku Pendidikan Tinggi di Masa Pandemi Covid-19: Pengabdian Perguruan TInggi di Masa Pandemi Covid-19.

Kemendikbud_A. (2020). Surat Edaran Menteri Pendidikan dan Kebudayaan Nomor 4 Tahun 2020 tentang Pelaksanaan Kebijakan Pendidikan dalam Masa Darurat Penyebaran Coronavirus Disease (COVID-19). 1-3. https://covid19.hukumonline.com/wpcontent/uploads/2020/04/surat_edaran_menteri_pendidikan_dan_kebud ayaan_nomor_4_tahun_2020-2.pdf

LPPM_UNIFLOR. (2021). Keputusan Rektor Universitas Flores Nomor 17 Tahun 2021 tentang Pembentukan Panitia Pelaksana Kuliah Kerja Nyata.

P3KKN_UNIFLOR. (2021). SISTEMATIKA PENULISAN LAPORAN KKN. P3KKN Universitas Flores, LPPM_UNIFL.

Rosaria, D., \& Novika, H. (2018). Bimbingan Belajar Bahasa Inggris Bagi Anak Usia Sekolah Dasar (6-12 Tahun) Di Desa Semangat Dalam Rt.31Handil Bhakti. Jurnal Pengabdian Al-Ikhlas, 2(2), 13-19. https://doi.org/10.31602/jpai.v2i2.751

SekJend_Kemendikbud. (2020). Surat Edaran Sekretaris Jenderal Kemendikbud Nomor 15 Tahun 2020 tentang Pedoman Penyelenggaraan Belajar dari Rumah dalam Masa Darurat Penyebaran Corona Virus Disease (Covid-19). 35. 